\title{
Relevancy and Admissibility of Medical Expert Witness in Illicit Intercourse under Shari'ah Law
}

\author{
Ahmad Azam Mohd Shariff \\ Ramalinggam Rajamanickam \\ Haritarshini Selvaraj \\ Kho Feng Ming \\ Nurul Fatihah Mohammad Arof \\ Nurleen Vanieysa Mohd Zulkifar \\ Nur Fasihah Selamat \\ Adib Ashman Burhan Burhanudin \\ Faculty of Law, \\ Universiti Kebangsaan Malaysia (UKM), \\ Malaysia
}

Doi: 10.36941/ajis-2019-0025

\section{Abstract}

The opinion of an expert witness is an important aspect in the law of evidence. As opposed to general witnesses testifying in court on perceived facts, expert witnesses testify based on their area of expertise. Such expert opinions on specific area of expertise assists the court in understanding special or scientific issues beyond the knowledge of common people. This article adopts the doctrine of pure legal research as its framework. Adopting a qualitative approach, methodologies of content analysis and critical analysis are used in analyzing archived materials. This article discusses on the relevancy and admissibility of evidence provided by medical expert witnesses in Malaysia. Special attention is given to Malaysian syariah illicit intercourse cases. The opinions of the four mazhabs on this area of law are highlighted. This writing further dissects the current Shari'ah legislations in Malaysia and compares them with the Malaysian civil legislations. During analysis, the authors find that there are definitely gaps in the current Malaysian Shari'ah evidence enactments. These gaps must be ironed out if we are to witness a better implementation of shari'ah evidential principles regarding expert witnesses during syariah court trials in future.

Keywords: relevancy; admissibility; expert witness; illicit intercourse; Shari'ah evidence enactments

\section{Introduction}

Evidence given by an expert is known as al-ra'yu al-khabir or al-khabir. Islamic law recognises opinion evidence given by an expert witness and it is the duty of the court to seek for advice from a person who is skilled in a particular field when facing a perplexing issue. The reasons behind it are, inter alia, judges are normal human beings possessing limited knowledge, and it is proper for the court to seek for advice from experts in a certain field to assist the court in upholding justice (Saedon, 1996). 
Ibn' Qayyim defines expert evidence as a testimony of a person skilled in a certain field (Ibn Qayyim, 1995). The expert is termed as al-khabir and the opinion given by an expert is based on a high standard of specialised knowledge (Azam, 2012). In simple words, expert evidence means testimony given in relation to some scientific, technical or professional matters by experts who are qualified to speak authoritatively by reason of their special training, skill or familiarity with the subject. It is important to bear in mind that an expert witness does not testify in court concerning the facts in dispute, but draws inferences from those facts using his knowledge, skill, experience, training or education. His testimony is to assist the court to arrive to a fair and just decision.

\section{Research Design and Methodology}

This article adopts the pure legal method as its research design using doctrinal and qualitative approaches. Library research method is used in gathering materials and data on expert and scientific evidence, qarinah and circumstantial evidence, principles on relevancy and admissibility of qarinah, expert and scientific evidence as well as principles on chain of custody and chain of evidence. Data on applicability of these principles in current Malaysian syariah illicit intercourse cases as well as related provisions in syariah and civil Malaysian legislations are also gathered. These materials and data are then analyzed via the methodologies of content analysis and critical analysis (Ramalinggam Rajamanickam et al. 2015).

\section{Relevancy and Admissibility of Medical Expert Witness: Position under Shari'ah Principles and Provisions}

Indeed, syariah evidential principle does give great importance to the opinion of an expert, and did recognised evidence given by an expert as a means of proof. For instance, in the Holy Book of alQur'an, An-Nahl: 43 and Al-Anbiya: 7

"...And We sent not before you except men to whom We revealed [Our message]. So ask those who know if you do not know."

Based on the verses provided, the phrase 'those who know' could well be interpreted as those who have expertise in their respective fields (Anwarullah, 2004).

According to one Sunnah of the Prophet, one of the Muslim warriors was hit on the head by a flinging stone. He then asked his comrades-in-arms for permission to use sand instead of water for ablution before prayer. The permission was denied and he died after washing his head with water. The Prophet, upon being notified about the incident, became angry and said that if the warriors were ignorant of a medical issue, they should have consulted experts and avoided taking matters in their own hands. The above Sunnah is a further proof that Opinions of experts are often consulted during any incident or inquiry during the time of the Prophet (Fatihah et.al., 2018).

In the case of a Madinese woman, the woman had accused the defendant of raping her against her will. In fact, she claimed that the stains on her dress and thigh are seminal stains belonging to the defendant. However, Umar al-Khattab, in acquitting the defendant, had relied on the finding that the so called seminal stains were only egg white smeared purposely on her dress and thighs to resemble seminal stains. The truth was found out when hot boiling water was poured onto the plaintiff's dress, resulting in the stains turning into egg white. It was found out that the woman had spilled the white of an egg on her dress and thigh in order to take revenge on him for rejecting her. The above incident has been cited by Ibn Qayyim as an example of an expert possessing special knowledge as well as expertise in the said field beyond the knowledge and skill of an ordinary person.

The Syafie and Hanafi schools of thought allow experts to be summoned so as to decide on issues which are in their area of expertise. For example, when a dispute occured between a buyer of a slave and the seller concerning physical defects in the slave discovered by the buyer soon after taking possession of the slave. The buyer argued that the defect originated when the slave was still in the ownership of the seller, who concealed any information about the defect. The seller 
contended otherwise saying the defect occurred after the contract was concluded and that the buyer had no ground for compensation or to annul the contract and get his money back. In such a case, reference and consultation with physicians were allowed to determine issue at hand. Some Hanafi jurists agree that two expert physicians must be called to testify whether or not the injury is 'old.' However, others agree that only one physician need to be summoned (Fatihah et.al., 2018).

Maliki jurists are of the opinion that testimony of an expert witness is objective and professional. Thus, they should not be subjected to rebuttal unlike ordinary testimonies. This is supported by the jurist Ibn' Hisham about the non-existence of rebuttal in expert testimony because they are not asked to come to the court to testify. In fact, experts are present to convey professional opinions based on their knowledge and expertise. As such these experts should not be subjected to any rebuttal or cross examination (Fatihah et.al., 2018).

Ibn' Farhun, Ibn' Qayyim al-Jawziyya and Ibn' Taymiyya later developed principles on admissibility of qarinah or circumstantial evidence. According to them, physical evidence surrounding an incident could be regarded stronger than oral testimony of a witness as an ordinary witness has the tendency to lie whereas evidence taken from surroundings does not (Ibn Qayyim, 1995). It was emphasized that an expert witness plays a major role in interpreting physical evidence and indicators based on their vast knowledge, skill and expertise. Hence, such professional and objective testimony should not be subjected to restrictions based on number and gender as well as rules pertaining to testimony given by regular witness. There are some differences of views among the Maliki jurists on this. Some are of the opinion that two expert testimonies are required while other jurists say that a testimony of one expert is suffice. In fact, Ibn Rusyd went further by saying that a testimony of one female or a non-muslim expert is considered sufficient (Fatihah et.al., 2018).

Ibn' Qudama from the Hanafi school stressed the importance of having two upright expert witnesses. Meanwhile, another jurist by the name of Al Khiraqi was of the opinion that rules for regular witness can be set aside for special circumstances. He emphasized that it is permissible to rely on one female expert witness in evaluating female physical intimate injury as only female witness is permissible to see and evaluate the subject matter in question. To sum up this argument, Ibn' Qayyim al-Jawziyya opined that the justification to comply with two upright expert male witnesses are subject to necessity (Fatihah et.al., 2018).

Evidence of an expert is expressly provided for in section 33 and section 34 of Malaysian syariah court evidence enactments. In fact, evidence of an expert is even referred to as 'qarinah.' Sub-sections 1, 2 and 3 of section 33 Shari'ah Court Evidence (Federal Territories) Act 1997 provide as follows:

(1) When the Court has to form an opinion upon a point of foreign law or of science or art, or as to identity or genuineness of handwriting or finger impressions or relating to determination of nasab, the opinions upon that point of persons specially skilled in that foreign law, science or art, or in questions as to identity or genuineness of handwriting or finger impressions or relating to determination of nasab, are qarinah.

(2) Such persons are called experts.

(3) Two or more experts shall be called to give evidence where possible but if two experts are not available, the evidence of one expert is sufficient. If two experts give different opinions a third expert shall be called to give evidence.

It is important to note that under the Evidence Act 1950, in order for a medical expert witness to be admitted as a piece of evidence in court, it must be deemed to be relevant by law. According to section 3 of the said Act, one fact is said to be relevant to another when it is connected with the other in any of the ways referred to in the provisions of the Act relating to relevancy of facts.

Do syariah principles and provisions require evidence of an expert to be relevant to the fact in issue or relevant facts of a case? The authors respectfully argue that they do. The above relevancy principle is indeed in sync with one of the most fundamental syariah evidential principle agreed upon by many sunni scholars. The said principle is named the principle of qarinah al zahirah which requires admission of a strong qarinah during any syariah court trial should the quantum of yaqin or zan al ghalib is to be met. Under this principle, there is indeed a strong need to ensure the strength of each qarinah before admitting it in court in the absence of witnesses of syahadah or a confession of iqrar (Azam, 2012). There are several means of ensuring its strength, one of which is to ensure 
that such qarinah is relevant to any fact in issue or relevant facts of the case. Therefore, it is hereby argued that since an expert evidence is a form of qarinah, there is indeed a need to ensure its relevancy to the fact in issue or relevant facts of the case before such expert evidence could potentially become strong and admissible. Consequentially, once a qarinah, such as in the form of an expert evidence, becomes potentially strong by virtue of its relevancy, it will simultaneously play an important and significant role in fulfillment of the quantum of yaqin or zan al ghalib during trial (Munzil et.al., 2015).

It is further argued that even though the Malaysian syariah evidence enactments do not use the term 'relevant' as in Evidence Act 1950, it does not mean that the principle of relevancy is not being appreciated at all by the Shari'ah principles and provisions. In fact, the fact that section 3(1) of these enactments, which regards 'qarinah' as a fact which is connected to another fact, indirectly indicates that a factual 'qarinah' must always be relevant to other facts in question in a trial. Such argument strengthens the fact that the provisions regarding expert evidence under section 33 and section 34 do require expert evidence to be relevant to the fact in issue or relevant facts. Hence, it could safely be regarded that one of the many requirements for an expert evidence to be admitted in the syariah court under section 33 and section 34 of our Malaysian syariah evidence enactments is that such expert evidence must be relevant to the fact in issue, or to any other facts which are relevant to the case.

Overall, the above syariah principles and provisions acknowledge relevancy and admissibility of expert evidence in general and medical expert evidence in particular. In the event where the court requires assistance from experts, the court must summon experts in the field in issue for testimony. Hence, in cases involving illicit sexual intercourse, it is relevant to summon a medical practitioner as expert witnesses to testify. Without assistance from experts in this area, it would be difficult for the prosecution to establish a prima facie case against the accused. Once expert evidence is adduced during trial, it is then the duty of the court to weigh the opinion evidence provided by such expert before deciding whether or not an offence of zina has been committed.

\section{Evidence of Expert Witness under the Evidence Act 1950}

In Malaysia, the general principle of the law of evidence in civil courts is that all facts that are relevant to the facts in issue or relevant facts are admissible as provided in section 5 of Evidence Act 1950. In determining whether or not a fact is a relevant fact to the case, the fact which sought to be proved by means of evidence must be those falling under any of those in sections 6 to 55 of the Act (Ramalinggam Ramalinggam et al., 2019), regardless of whether it fulfils the criteria of common sense and logic as those required under the common law. This position could be seen in DPP $v$ Kilbourne [1973] AC 729; $R \vee$ Randall [2003] UKHL 69. The opinion evidence of an expert witness also falls within the scope, viz sections 45 . At this juncture, court shall only consider direct evidence of each witness: on what they perceived, the facts and not their opinion.

Opinion evidence is only relevant and admissible if it falls under the exception, viz especially when court requires evidence in opinion. Such category of opinion evidence is known as evidence of expert witness. Sarkar opined that opinion evidence is to assist the court to reach a conclusion in an area which court lacks knowledge of. If such opinion assists the court to fully understand the facts in issue, hence such evidence, though is in the form of opinion (not facts), can be considered by the court in making decision (Sarkar, 2018; Ramalinggam \& Anita, 2014). Conversely, if the court can decide a case without the need of the assistance of expert witness, hence the evidence of expert witness is not required. This was decided in R v Turner [1975] All ER at page 70. The test to decide whether there is a requirement of assistance of expert witness opinion evidence is the common knowledge rule. For instance, in a criminal proceeding, the onus of proof is on the prosecution to establish a prima facie case beyond reasonable doubt. Thus, testimony by a witness is often crucial in tendering evidence. As an illustration, in a murder case where the victim was killed with a weapon, the fact in issue to be addressed is whether the victim died due to the accused's conduct. In order to prove that, a post mortem must be carried out and it is not sufficient to present only the autopsy report but the maker of such document should be called as expert witness to furnish the court with necessary explanation. Nonetheless, it is important to emphasized 
that the evidence provided by an expert witness indeed is low probative value, for the reason that the evidence provided by them are in the form of opinion, not facts. Unlike facts, opinion varied from one to another, and an opinion differs from one expert to another expert.

Based on the provision section 45 of Evidence Act 1950 (which will be further discussed below), the court shall consider the opinion evidence provided by an expert witness when the case required such assistance on technical matter, and the court shall not decide on such matters in the absence of such evidence. It is erroneous for a judge to arrive to a conclusion on a matter which could only be properly concluded with the aid of expert evidence. Under section 45 of Evidence Act 1950, the evidence produced by expert witness is admissible (Lirieka, 2001). Expert evidence is significant in assisting the court to arrive at the right decision about an issue which is beyond the common knowledge and experience of a judge (Ramalinggam, 2017). It provides:

Opinion of experts

(1) When the court has to form an opinion upon a point of foreign law to science or art, or as to identity or genuineness of handwriting or finger impression, the opinion upon that point of persons specially skilled in that foreign law, science or art, or in questions as to identity or genuineness of handwriting or finger impressions, are relevant facts.

(2) Such persons are called experts.

From the provisions above, the civil jurisdictions in Malaysia (as opposed to the syari'ah jurisdiction) does accept expert opinion as an evidence in the court of law. It has a specific statute governing this kind of evidence, and it applies to both civil and criminal cases. An evidence provided by the expert can be ranging from, as the provisions stated, handwriting (Teng Kum Seng $v P P$ [1960] 1 MLJ 225), finger impressions (PP v Toh Kee Huat [1977] 1 MLJ 64), science (Gary, 2012), art (Chandrasekaran v PP [1971] 1 MLJ 153; Leong Wing Kong v PP [1994] 2 SLR 54), foreign law (PP v Forster Frank Edald Heinrich [1988] 2 MLJ 594; In the estate of Sim Siew Guan Deceased [1932] MLJ 95), so on and so forth, and these evidence are admissible if they are relevant to the facts in issue of a particular case (Field, 2005). The illustrations to section 45 went on to provide explanation of the working mechanism of this provision. For instance:

(a) The question is whether the death of $A$ was caused by poison.

The opinions of experts as to the symptoms produced by the poison by which $A$ is supposed to have died are relevant.

Hence, it illustrates how an evidence provided by an expert witness can be admissible in the court of law. The illustrations above provide instances on evidence pertaining to science. However, the Act itself did not provide the definition on what amounts to science (Ramalinggam, 2018). Nonetheless, in Chandrasekaran \& Ors v Pendakwa Raya [1971] 1 MLJ 153, Raja Azlan Shah J opined:

“... The expression 'science or art' is elastic enough to be given a liberal interpretation..."

Science is a profession on sustaining a control and balance to ensure accuracy (Bowen, 2010). It has also been defined as as a field of systematic knowledge and can be proven its truth (KPM,1993). In the case of Basudeo Gir v State AIR 1959 Pat 539, the court defines science as:

“... great proficiency, dexterity and skill based on long experience and practice..."

Hence, the technicality and knowledge on the medical field may fall under the scope of the word 'science', and as such, testimony with regard to medical field is admissible under the Evidence Act 1950.

For an expert witness evidence to be admissible under the Evidence Act, certain requirements have to be fulfilled (Ramalinggam et.al., 2012). Generally, the two tests that need to be satisfied before expert evidence can be admitted can be referred to the case in Junaidi bin Abdullah v Public Prosecutor [1993]3 MLJ 229 where it provides the evidence must be the one that requires special skill and the person giving the evidence must be a qualified person. The court opined:

“... In our view, the test to be applied for the purpose of s 45 of the Evidence Act 1950 is this. First, does the nature of the evidence require special skill? Second, if so, has the witness acquired the 
necessary skill either by academic qualification or experience so that he has adequate knowledge to express an opinion on the matter under enquiry? The answer to both questions must necessarily depend on the facts of each particular case..."

In the case of Pendakwa Raya Iwn. Muhamed bin Sulaiman [1982] 2 MLJ 320, the court pointed out that an expert must be 'skilled' via an official and special study or via experience. The fact that he has not acquired his knowledge professionally relates to weightage and not admissibility. While in the case of Ramsdale Iwn. Ramsdale 173 L.T. 393 in a situation where an opinion of the expert is based on facts provided in report, the facts are admissible but, must be proved independently unless, the facts are in the expert knowledge itself. For witness that is specifically summoned for the purpose of medical issue, the case of Sunil Chandra Roy Iwn State (1954) C. 305 held that the expert may provide the court with medical evidence as to prove that such injury may or may not be the cause of death.

From the above discussion, it appeared that the Evidence Act 1950 in Malaysia does accept the evidence provided by an expert witness. It may relate to areas such as handwriting, finger impressions, science, art, foreign law. However, the requirement which need to be satisfied for an expert witness is growing to the stage of great concern as illustrated above. Apart from this dilemma, generally, an evidence provided by an expert witness is admissible under the Evidence Act 1950 .

\section{Relevance of Scientific Proof in Malaysian Syariah Cases}

An expert opinion can be given in the form of evidence pertaining to scientific method, DNA test or forensic matters. For instance, an analysis done by a genetic expert often being used in cases where it involves a child that is born out of wedlock. According to Shari'ah Judiciary Department of Malaysia, it appeared that the Syarie Judges in Sabah had accepted Deoxyribonucleic Acid (DNA) as evidence where an expert witness been called to give opinion on such evidence and assist the court on that matter.

In Pendakwa Syarie Negeri Sabah Iwn. Rosli Bin Abdul Japar (2007) 23/2 JH 237, the accused was convicted for having illicit intercourse under section 80(1) Shari'ah Criminal Offences Enactment (Sabah) 1995. The said provision provides:

Section 80: Forbidden sexual intercourse.

(1) Any male person who commits forbidden sexual intercourse with another female person shall be guilty of an offence and shall, on conviction, be liable to a fine not exceeding five thousand ringgit or to imprisonment for a term not exceeding three years, or to canning not exceeding six strokes or any combination of such punishments.

The accused had caused the woman to give birth to a child out of wedlock. The High Court of Keningau had admitted the arguments by the Syarie Prosecutor that there was a strong qarinah to link the relationship of the accused with the birth of the illegitimate child which was successfully proven through scientific method. However, the defense counsel had argued that the Syarie prosecutor had failed to call four (4) witnesses as per required under section 86(1) of Shari'ah Courts Evidence Enactment 1992 that provides:

Section 86: Number of witnesses.

(1) No evidence in a zina case which incurs punishment according to hudud is admissible except if it is witnessed by four male persons.

However, the court opined such provision did not apply in this case since hudud punishment does not take place in this country. However, the court ruled the accused can be convicted under ta'zir punishment by admitting other evidence in the absence of four (4) male witnesses. In this case, the court was assisted by expert evidence and through scientific verification via DNA test on the three contributors of the blood specimens. The tests were conducted by a DNA expert from the Chemistry Department of Malaysia, Petaling Jaya. Upon conviction of the crime, the accused was punished by fine amounting to RM3,000.

The same circumstances can be seen in the case of Pendakwa Syarie Negeri Sabah Iwn. Mad Ranger (2001) S-3/95-7. The accused was charged and convicted of committing illicit 
intercourse under section 80(1) Shari'ah Criminal Offences Enactment (Sabah) 1995. The Kota Kinabalu High Court of Shari'ah accepted expert witness evidence based on DNA test that had been carried upon the accused and the child that was carried by the accused's partner.

The authors are of the opinion that the decision by the Syarie Judges in Sabah in accepting scientific method and expert opinion in convicting an accused should be recognized and followed by other states in this country. This proves acceptance and admissibility of scientific as well as expert evidence by syariah evidential principles and the Shari'ah courts. Clearly the modern scientific and technological based evidence are able to assist the syariah court in making court decisions.

\section{Relevancy and Admissibility of Expert and Scientific Evidence: Recommendations}

From the discussions above, it appeared that under the civil jurisdiction, viz Evidence Act 1950, the evidence provided by expert witnesses when relevant, will be admissible in the court of law. This is provided under section 45 of the statute. It is important to realize that the evidence provided by an expert witness is indeed in the form of opinion and, not facts. As such, the probative value of the expert evidence is lower than that of other ordinary witnesses and as such is not capable of being the sole ground for conviction. Despite this, expert and scientific evidence still play a massive role when deciding on facts in issue or relevant facts during a trial. The evidence provided by an expert witness is for the purpose of assisting the court in the event when the court is unable to decide a case without the assistance of expert witness who is specialized in their respective field. The test as to whether to invoke the assistance of expert witness is the common knowledge rule. In other words, if the court is able to decide on the subject matter without the need to call an expert witness, hence the expert witness is not required and vice versa.

From the Shari'ah perspective, illicit intercourse (zina) is an offence under hudud that carries the punishment of either death or one hundred lashes. For a hudud offence to be punishable under hudud punishment, the evidence submitted must satisfy the quantum of yaqin. There must be sufficient and convincing proof beyond doubt that a hudud offence has been committed by the accused before the hudud punishment can be imposed on him. Al Quran surah An Nur: 2 provides:

"The [unmarried] woman or [unmarried] man found guilty of sexual intercourse - lash each one of them with a hundred lashes, and do not be taken by pity for them in the religion of Allah, if you should believe in Allah and the Last Day. And let a group of the believers witness their punishment."

During the Prophet's time and The Rashidun Caliphs era, conviction of hudud offences is based on confession (iqrar) and testimony of witness (shahadah). Takzir punishment will be imposed if there is insufficient evidence to convict the accused under hudud. This is when expert and scientific evidence play a more significant role as such evidence could very well assist the court in convicting and sentencing the accused under takzir (Munzil et.al, 2015).

As far as the syariah court evidence enactments are concerned, there are some legal provisions pertaining to expert opinion which are more or less in pari materia with the Evidence Act 1950. Nonetheless, the authors argue that these provisions are still insufficient. First of all, it does not provide when an expert evidence is in fact required (as provided in the common knowledge rule in $R v$ Turner). Secondly, the position on whether the judge is bound to admit such evidence in his judgement is still unclear. Thirdly, there is no guideline for the judges on how to elect which opinion to be preferred when there is more than one expert witness being called. Fourthly, provisions regarding qarinah should be further refined so that enhancement could be inserted in the enactments regarding its definition, scope as well as strength. Having a clearer and detailed provisions on qarinah in the states' enactments would assist application and admissibility of expert and scientific evidence in general. Last but not least, several provisions regarding principles on chain of custody and chain of evidence should urgently be incorporated into the enactments as both principles support applicability and admissibility of expert and scientific evidence. Both principles ensure that all scientific-related items seized are not tampered with and are kept in proper and safe custody throughout. It also ensures that the chain of evidence stays intact in proving that these 
expert and scientific evidence point at existence of any fact in issue or relevant facts of the case.

\section{Conclusion}

In conclusion, the general principle is that medical expert witnesses in illicit intercourse (zina) is relevant and admissible as qarinah under Shari'ah law. Such a position is based on injunctions from al Quran and al Sunnah, juristic views as well as legal provisions in syariah court evidence enactments. Even though expert evidence has a lower probative value as compared to ordinary witnesses owing to the fact that it is just a mere opinion, its admissibility cannot be discounted as it has an important role to play in proof of takzir conviction and punishment. Its important role is further amplified by the fact that such opinion based evidence is still based on the expert's expertise in related field relating to fact in issue or relevant facts under the court's scrutiny. However, there are gaps in legal provisions regarding expert evidence. It is felt that these provisions must be amended if we are to see a more systematic and efficient implementation of syariah principles on medical expert evidence in the Malaysian syariah court in future.

\section{Acknowledgement}

This research is funded by Universiti Kebangsaan Malaysia (UKM) through research grant i.e. GGPM-2017-019.

\section{References}

Ahmad Azam Mohd Shariff. (2012). Prosedur Siasatan dan Pendakwaan Kes Jenayah Syariah: Lakuna Dalam Perundangan Jenayah Syariah di Malaysia. (Doctoral Dissertation). Universiti Kebangsaan Malaysia, Bangi, Malaysia.

Anwarullah, P. D. (1999). Principles of Evidence in Islam. Kuala Lumpur: A.S. Noordeen.

Bowen, R. T. (2017). Ethics and the practice of forensic. Boca Raton: CRC Press.

Edmond, G., \& Roque, M. S. (2012). The cool crucible: Forensic science and the frailty of the criminal trial. Current Issues in Criminal Justice, 24(1), 51-68.

Field, C. D. (2005). Field's Expert Evidence: Expert Evidence and Opinions of Third Person (Medical and NonMedical). India: Delhi Law House.

Ibn Qayyim. (1995). Turuq al-Hukmiyah fi al Siyasah al Syari'yyah. Beirut: Darul Kutub al Ilmiyyah.

Kementerian Pendidikan Malaysia. (1993). Kamus Pelajar Bahasa Malaysia: Terbitan Khas KBSM. Kuala Lumpur: Dewan Bahasa dan Pustaka.

Meintjies-Van Der Walt, L. (2001). Expert Evidence and the Right to a Fair Trial: A Comparative Perspective. South African Journal on Human Rights, 17(3), 301-319.

Mahmud Saedon. (1996). An Introduction to Islamic Law of Evidence. Shah Alam: Hizbi.

Mohd Munzil Muhamad, Ahmad Azam Mohd Shariff, Ramalinggam Rajamanickam, Mazupi

Abdul Rahman, Anowar Zahid, \& Noorfajri Ismail. (2015). Qarinah: Admissibility of Circumstantial Evidence in Hudud and Qisas Cases. Mediterranean Journal of Social Sciences, 6(2), 141.

Nurul Fatihah Mohammad Arof, Haritarshini Selvaraj, Kho, F. M., Nurleen Vanieysa Mohd Zulkifar, Nur Fasihah Selamat, \& Adib Ashman Burhan Burhanudin. (2018). Does Testimony of a Medical Expert Admissible in Malaysian Syariah Cases?. Paper presented at Faculty of Law, Universiti Kebangsaan Malaysia, Bangi, Selangor.

Ramalinggam Rajamanickam. (2017). Skop Seksyen 45 Akta Keterangan 1950: Keperluan Untuk Semakan Semula. Jurnal Undang-Undang dan Masyarakat, 21(2).

Ramalinggam Rajamanickam, Anita Abdul Rahim, \& Anisah Che Ngah. (2012). Kerelevanan Keterangan Pakar Forensik di bawah Seksyen 45 Akta Keterangan 1950. The Law Review, 414.

Ramalinggam Rajamanickam, \& Anita Abdul Rahim. (2014). The position of psychological expert evidence under the Malaysian evidence act 1950. Mediterranean Journal of Social Sciences, 5(14), 128.

Ramalinggam Rajamanickam, Saw, W. S., Anisah Che Ngah, \& Rizal Rahman. The position of similar fact evidence in Malaysia. (2015). Mediterranean Journal of Social Sciences, 6(4), 539.

Ramalinggam Rajamanickam et al. (2019). The Assessment of Expert Evidence on DNA in Malaysia. Academic Journal of Interdisciplinary Studies, 8(2), 51-57.

Sarkar, S. C. (2018). Law of Evidence, Vol 1. Selangor: Lexis-Nexis. 